\title{
DERAJAT INFEKSI DAN TINGKAT PREVALENSI CACING Anisakis sp PADA IKAN TONGKOL (Euthynnus affinis) DI TPI KOTA PEKALONGAN
}

\author{
Linayati \\ Staf Pengajar Fakultas Perikanan Universitas Pekalongan
}

\begin{abstract}
ABSTRAK
Tujuan penelitian ini adalah untuk melihat derajat infeksi dan prevalensi kehadiran Anisakis $s p$ di dalam tubuh ikan tongkol. Pelaksanaan penelitian pada bulan Maret 2017 di TPI kota Pekalongan. Ikan tongkol yang digunakan adalah ikan dengan ukuran 19-24 Cm sebagai kelompok pertama dan 25-33 cm sebagai kelompok kedua. Jumlah ikan yang digunakan sebanyak 50 ekor ikan yang terbagi menjadi 2 kelompok di atas. Dalam penelitian ini pengamatan kehadiran cacing Anisakis $s p$ dilakukan pada organ dalam tubuh ikan yaitu usus, lambung, hati dan juga otot ikan. Hasil pengamatan menunjukkan bahwa Derajat Infeksi ikan sebesar 12,6 pada ukuran 19-24 cm, sedangkan Derajat infeksi pada kelompok 25-31 cm sebesar 16,5. Sedangkan nilai prevalensi pada ikan kelompok ukuran pertama $60 \%$ dan kelompok ukuran kedua $88 \%$. Nilai tersebut termasuk ke dalam kriteria tinggi. Jumlah Anisakis $s p$ yang terbesar terdapat pada organ usus karena organ tersebut merupakan bagaian tubuh yang merupakan sumber makanan bagi cacing Anisakis $s p$. Pada kedua kelompok cacing Anisakis $s p$ pada usus ditemukan lebih dari 100. Sedangkan cacing Anisakis $s p$ ditemukan paling sedikit jumlahnya pada bagian hati berkisar $10-36$.
\end{abstract}

Kata kunci : Anisakis sp, Prevalensi, Derajat Infeksi, TPI Pekalongan

\begin{abstract}
The objective of this study was to look at the degree of infection and the prevalence of Anisakis sp presence in the body of Euthynnus affinis . research was conduct in March - April 2017 at TPI (fish auction) of Pekalongan city. The length of fish used are $19-24 \mathrm{~cm}$ fish as the first group and $25-33 \mathrm{~cm}$ as the second group. The number of fish used as many as 50 fish that is divided into 2 groups as above. In this study, observation of the presence of Anisakis sp worms carried on the organs in the fish body of the intestine, stomach, liver and fish muscles. The results showed that the degree of fish infection was 12.6 in size 19-24 $\mathrm{cm}$, while the degree of infection in the $25-33 \mathrm{~cm}$ group was 16.5 . While the prevalence value in fish group size of first $60 \%$ and group size second $88 \%$. The value belongs to the highly infection criteria. The largest amount of Anisakis $s p$ found in the gut organs because on that organs is full of food which needed to grow for parasit. In both groups of Anisakis sp worms found in the intestine more than 100, while in the liver ranged from 10 to 36 .
\end{abstract}

Keyword: Anisakis sp, Prevalensi, Degree of Infection, Fish Auction, Pekalongan 


\section{PENDAHULUAN}

TPI kota Pekalongan adalah salah satu TPI yang berlokasi di daerah pesisir utara jawa dan memiliki peranan penting untuk perkembangan industri perikanan di daerah pekalongan dan sekitarnya. Hasil tangkapan ikan laut yang mendominasi TPI kota Pekalongan adalah ikan laut ekonomis yang tidak hanya menjadi konsumsi dalam negeri namun juga luar negeri. Salah satu diantaranya ikan laut ekonomis yang banyak dilelang di TPI Kota Pekalongan adalah ikan tongkol (Statistik Kota Pekalongan, 2016). Ikan ini termasuk dalam kelas Scrombidae yang dapat ditemukan di banyak daerah di Indonesia. Kandungan gizi yang tinggi dengan komposisi protein $25 \%$, lemak 1,5 $\%$ dan karbohidrat $0.03 \%$ (Sanger, 2010) menjadikan ikan ini menjadi salah satu ikan laut yang banyak dikonsumsi. Permintaan yang terus meningkat dan harga yang tinggi menunjukkan bahwa sektor penangkapan ikan tongkol sangat menjanjikan. Ikan tongkol juga merupakan ikan yang menjadi tujuan penangkapan oleh nelayan.

Dalam perkembangan industri perikanan, kehadiran parasit adalah adalah salah satu kendala yang sering ditemui. Hal ini disebabkan ikan adalah inang yang potensial bagi bermacam macam parasit, termasuk diantaranya adalah Nematoda. Salah satu cacing yang termasuk golongan Nematoda adalah Anisakis sp. Cacing Anisakis sp sering menyerang ikan laut jenis karnivora seperti ikan tongkol yang memakan ikan kecil, cumi dan udang kecil. Pakan yang dikonsumsi ikan tongkol inilah yang menjadi inang perantara cacing untuk menginfeksi ikan. Hal ini menyebabkan kontak parasit Anisakis sp dengan ikan jauh lebih banyak (Rohde, 1994). Menurut Hasan et al (2013) ikan yang terinfeksi cacing Anisakis sp menunjukkan gejala seperti adanya perubahan degeneratif, inflamasik dan terjadi nekrosis pada hepatopancreas. Infeksi parasit Anisakis $s p$ memiliki dampak zoonosis yaitu satu kondisi dimana cacing dapat dapat berpindah ke manusia yang sering disebut dengan penyakit anisakiasis. Hal ini dapat terjadi karena manusia memakan ikan dalam konsisi mentah atau tidak matang sempurna. Gejala yang timbul akibat penyakit anisakiasis diantaranya adalah gangguan pencernaan, gastroenteristis, muntah, reaksi alergi, diare dan nyeri perut (Pozio, 2013). Kehadiran Anisakis sp pada ikan air laut dikhawatirkan juga akan mempengaruhi kualitas produksi ikan dalam kaleng yang banyak berasal dari ikan jenis Scrombidae. 
Meskipun parasit Anisakis sp ini memberikan dampak negatif pada ikan, manusia dan juga kemungkinan berpengaruh pada penurunan kualitas produk ikan dalam kaleng, namun studi tentang cacing Anisakis sp pada ikan laut yang banyak di konsumsi masyarakat pesisir utara Pulau Jawa masih terbatas. Penelitian ini bertujuan untuk mengetahui infeksi dan distribusi cacing Anisakis sp yang terdapat organ dalam ikan tongkol yang dipasarkan di TPI Kota Pekalongan. Hasil penelitian ini diharapkan dapat menjadi informasi tambahan untuk masyarakat dan instansi terkait tentang parasit Anisakis sp sehingga dapat meningkatkan kewaspadaan serta pencegahan terhadap penyakit anisakiasis.

Tujuan penelitian ini adalah untuk menghitung derajat infeksi dan prevalensi kehadiran cacing Anisakis sp dalam tubuh ikan tongkol pada ukuran panjang yang berbeda. Selain itu dalam penelitian ini juga mengamati distribusi cacing Anisakis $s p$ pada organ dalam tubuh ikan Tongkol

\section{METODE PENELITIAN}

Bahan yang digunakan dalam penelitian ini adalah ikan tongkol yang didaratkan di TPI kota Pekalongan pada bulan Maret - April 2017. Jumlah Ikan yang digunakan sebagai sampel sebanyak
50 ekor ikan tongkol dengan panjang antara 25-33 cm. Ikan tersebut dikelompokan menjadi 2, dengan ketentuan kelompok I adalah ikan dengan ukuran 19-24 cm dan kelompok kedua 25$33 \mathrm{~cm}$. Sampel ikan diawetkan menggunakan ice box yang diisi dry es dengan harapan dapat memperlambat proses pembusukan. Data yang diperoleh ditabulasikan dan kemudian dijelaskan secara deskriptif.

Pemeriksaan sampel dimulai dengan melakukan sayatan, dimulai dari kloaka ikan ke arah anterior sampai posisi operculum untuk mengambil organ pencernaan yaitu lambung dan usus. Selain itu pemeriksaan juga dilaksanakan pada hati serta rongga tubuh ikan. Sebelum pengamatan organ lambung, usus dan hati direndam terlebih dahulu dengan larutan fisiologis $(\mathrm{NaCl} 0.9 \%)$ dan ditambahakan sedikit buffer formalin $5 \%$ untuk mengawetkan kondisi organ. Selanjutnya isi dari lambung dan usus di keluarkan secara perlahan dan isi tersebut diletakkan dalam petridish yang berbeda. Pengamatan keberadaan cacing Anisakis sp dimulai dengan mata telanjang, menggunakan loop dan yang terakhir adalah mikroskop. Jaringan otot pada ikan juga diperiksa dengan cara membuat irisan pada otot 
secara perlahan dengan posisi arah mendatar. Apabila ditemukan cacing Anisakis sp maka segera diambil menggunakan pinset dan diletakkan dalam petridish yang telah diisi larutan fisiologis dan buffer. Penghitungan derajat infeksi (DI) Anisakis sp menggunakan rumus sebagai berikut (Rucket et al, 2009) :

$\mathrm{DI}=\frac{\text { Jumlah total parasit yang menginfeksi inang }}{\text { Junlah ikan yang terinfeksi }}$

Prevalensi $=\frac{\text { Jumlah } \text { ikan yang terinfeksi }}{\text { Jumlah Ikan yang diperiksa }} \times 100 \%$

\section{HASIL DAN PEMBAHASAN}

Perhitungan derajat infeksi adalah untuk melihat jumlah rata rata parasit yang menyerang ikan yang terinfeksi parasit. Parasit yang dimaksud adalah Anisakis sp dan objek ikan yang terinfeksi adalah ikan tongkol yang didaratkan/dilelang di TPI kota Pekalongan. Dalam penelitian ini dilakukan perbandingan jumlah parasit Anisakis sp pada organ dalam ikan untuk melihat distribusi cacing dan lokasi preferensial bagi parasit tersebut.

Tabel 1. Jumlah Cacing Anisakis sp Pada Kelompok I dan II

\begin{tabular}{lcc}
\hline Nama Organ & $\begin{array}{c}\text { Jumlah } \\
\text { Parasit } \\
(19-24 \mathrm{~cm})\end{array}$ & $\begin{array}{c}\text { Jumlah } \\
\text { Parasit } \\
(25-33)\end{array}$ \\
\hline Lambung & 53 & 96 \\
\hline Usu & 103 & 177 \\
\hline Hati & 10 & 36 \\
\hline
\end{tabular}

\begin{tabular}{lll}
\hline Jaringan Otot & 24 & 54 \\
\hline
\end{tabular}

Tabel 2. Perbandingan Prevalensi dan Derjat Infeksi Kelompok I dan II

\begin{tabular}{|c|c|c|c|c|c|}
\hline Ukuran & $\begin{array}{c}\text { Jml } \\
\text { sampel } \\
\text { yang } \\
\text { diperiksa }\end{array}$ & $\begin{array}{c}\text { Jml } \\
\text { sampel } \\
\text { yang } \\
\text { terinfeksi }\end{array}$ & $\begin{array}{c}\text { Jml } \\
\text { Parasit }\end{array}$ & P (\%) & DI \\
\hline $19-24 \mathrm{~cm}$ & 25 & 15 & 190 & $60 \%$ & 12.6 \\
\hline $25-33 \mathrm{~cm}$ & 25 & 22 & 363 & $88 \%$ & 16.5 \\
\hline
\end{tabular}

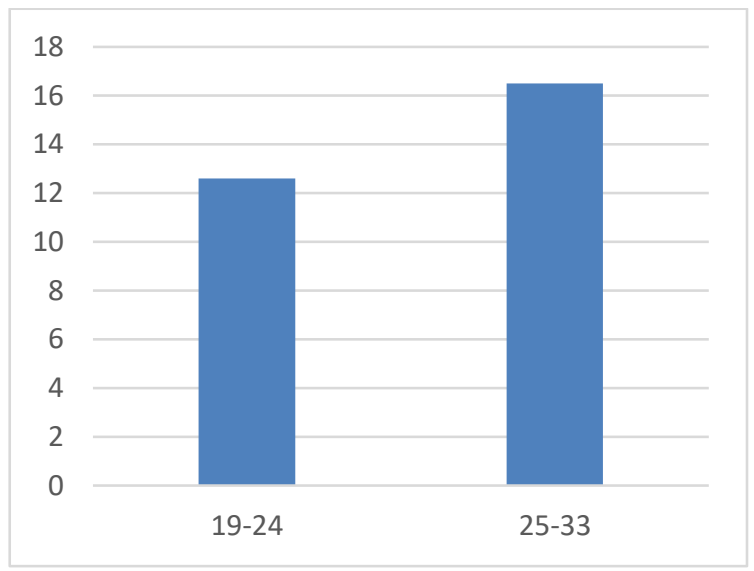

Gambar 1. Perbandingan Derajat Infeksi

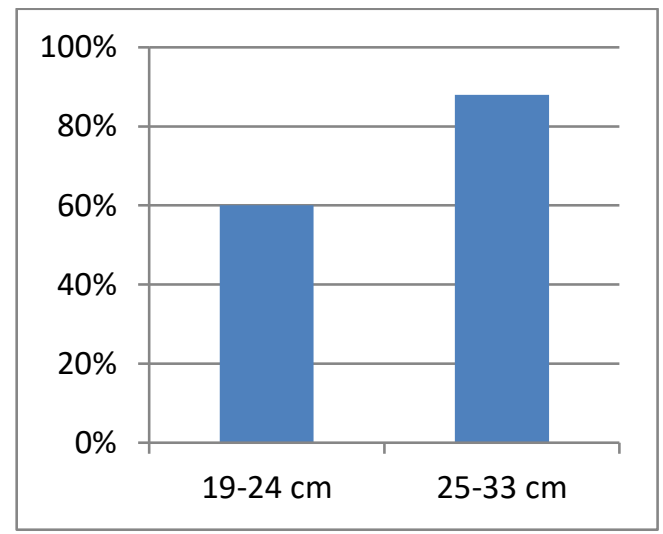

Gambar 2. Perbandingan Prevalensi antara 2 kelompok ukuran

*Sumber : Hasil Penelitian

\section{Derajat Infeksi}

Parasit Anisakis sp yang diperoleh dalam penelitian ini bewarna putih dengan bentuk bulat memanjang dengan panjang cacing antara 1-2cm. Morfologi parasit 
yang ditemukan sesuai dengan pernyataan Awik et al (2007) bahwa Anisakis sp memiliki warna tubuh putih dengan panjang berkisar 10- $20 \mathrm{~mm}$. Berdasarkan data pada gambar 1 di atas terlihat ada perbedaan Derajat Infeksi (DI) pada 2 kelompok ukuran, yaitu ukuran kelompok kedua 25-33 cm lebih tinggi yaitu 16,5 dibandingkan dengan kelompok ikan dengan panjang 19-24 cm sebesar 12,6. Ikan yang lebih besar memiliki persediaan makanan yang lebih besar dari pada ikan kecil sehingga kompetisi parasit memperebutkan makanan hampir tidak ada. Semua kebutuhan Anisakis sp terdapat pada ikan besar sehingga kemungkinan pindah ke ikan yang lebih kecil sedikit. Hal ini menyebabkan infeksi parasit Anisakis sp pada ikan yang lebih besar nilainya lebih tinggi. Noble and Noble (1989) menjelaskan bahwa kurangnya kompetisi antar parasit dalam lingkungan menyebabkan jumlah Anisakis sp pada ikan yang lebih besar akan meningkat. Parasit Anisakis sp ditemukan pada organ usus, lambung, hati dan jaringan otot. Kelompok pertama ukuran (19-24 cm) pada usus sebanyak 103 disusul lambung sebesar 53, kemudian jaringan otot 24 dan yang terakhir hati sebanyak 10. Untuk kelompok kedua dengan ukuran $25-33 \mathrm{~cm}$ juga mengindikasikan hasil yang sama dimana Anisakis sp ditemukan paling banyak di usus 177 ekor. Jumlah Anisakis $s p$ selanjutnya sebanyak 96 di organ lambung dan paling kecil adalah di hati sejumlah 54 ekor. Hal ini mengindikasikan bahwa cacing Anisakis sp terdistribusi pada organ dalam pada ikan tongkol dengan preferensial di organ usus. Hal ini disebabkan karena usus mengandung banyak makanan dari pada di lambung, hati maupun jaringan otot. Habitat yang mendukung untuk parasit adalah tempat yang banyak tersedia makanan, oksigen, maupun faktor lainnya seperti kompetisi antar spesies (William and Jones, 1993). Sedangkan pada lambung adalah lokasi kedua ditemukan Anisakis sp terbanyak. Usus menjadi tempat preferensial karena beberapa faktor seperti kemudahan mendapatkan nutrisi dan usus merupakan sumber makanan. Dalam usus halus dengan mudah dapat ditemukan sel jaringan, cairan tubuh, darah dan juga sari sari makanan yang terkandung dalam lumen usus halus (Robert and Janov, 2000). Lambung merupakan tempat berkumpulnya makanan untuk dicerna sehingga lambung juga banyak mengandung nutrisi. Selain usus dan lambung, pada hati dan jaringan otot ikan tongkol ditemukan cacing Anisakis $s p$ meskipun dalam jumlah sedikit. Hal ini 
sesuai dengan pendapat Rohde (1994) yang menyatakan bahwa Nematoda Anisakis sp paling banyak terdapat saluran pencernaan meskipun dapat pula ditemukan pada organ lain dan jaringan tubuh ikan. Kemampuan Anisakis sp sebagai endoparasit dalam tubuh ikan ditunjang oleh sturuktur tubuh yang memiliki epidermis kulit yang mampu menjadi pelindung dari kerusakan oleh enzim enzim pencernaan. Lorenzo (2000) menyatakan keberadaan kutikula yang disekresikan oleh kulit Anisakis sp mampu melindungi Anisakis sp dari enzim dalam usus halus.

\section{Prevalensi}

Pengertian prevalensi sebagai persentase jumlah ikan yang terjangkit satu penyakit dalam satu populasi. Berdasarkan data yang diperoleh menunjukkan tingkat prevalensi di $60 \%$ dan $88 \%$. Perbedaan tingkat prevalensi menunjukkan adanya tingkat zoonosis yang lebih tinggi pada ikan dengan ukuran $25-33 \mathrm{~cm}$. Hal ini sesuai dengan hasil test $\mathrm{T}$ yang diujikan pada hasil pengamatan bahwa ukuran berpengaruh nyata terhadap jumlah Anisakis sp $\quad(\mathrm{P}<0.05)$. Hasil ini menunjukkan semakin panjang ukuran ikan tongkol maka semakin banyak jumalh Anisakis sp yang ditemukan. Hubungan antara ukuran dengan jumlah parasit Anisakis sp juga ditunjukkan oleh penelitian sebelumnya pada ikan layur (Trichiurus lepturus) yang menemukan hasil tingkat intensitas Anisakis sp yang lebih tinggi pada ukuran ikan layur yang lebih panjang (Semarariana et al, 2012). Keberadaan Anisakis sp dalam jumlah yang banyak pada ikan yang lebih besar disebabkan karena ikan yang lebih besar memiliki kemampuan bertahan hidup lebih lama sehingga kemungkinan untuk terpapar cacing Anisakis sp lebih tinggi dibanding ikan yang kecil. Hal ini sesuai dengan yang disebutkan oleh Noble and Noble (1989) bahwa beberapa hal yang mempengaruhi perilaku parasit yang menginfeksi inang adalah: umur, iklim dan musim, ukuran tubuh inang dan lokasi geografis. Selanjutnya bahwa jenis makanan yang dimakan oleh ikan juga mempengaruhi jumlah Anisakis sp yang ada dalam tubuh ikan. Semakin besar ikan maka semakin banyak makanan baik jenis maupun jumlah yang dikonsumsinya. Hal ini menyebabkan akumulasi parasit Anisakis sp pada tubuh ikan. Beberapa makanan ikan tongkol yang bersifat karnivora adalah ikan-ikan kecil, udang, serta cumi cumi. Siklus hidup Anisakis sp sebagai parasit menggunakan copepoda (udang kecil), dan ikan-ikan kecil sebagai 
inang perantara sebelum masuk ke ikan yang lebih besar. Kimple et al (2004). Menyebutkan bahwa copepoda serta ikan predator berukuran kecil dimungkinkan menjadi inang perantara intermediate untuk parasit Anisakis sp. Nilai prevalensi 60-88\% seperti data yang diperoleh menunjukkan nilai yang tinggi yang dapat berakibat buruk bagi manusia yang mengkonsumsinya dalam keadaan mentah. Menurut Zubaidy (2010), bahwa tingkat prevalensi antara $41-100 \%$ termasuk dalam kategori tinggi. Terdapatnya Anisakis sp pada tubuh ikan menunjukkan kualitas ikan yang buruk. Menurut Kobayasi et al (2008) dalam Polimeno (2010) menyebutkan bahwa keberadaan larva Anisakis sp dalam tubuh ikan maka kualitas daging ikan tersebut buruk dan dapat menyebabkan kemunculan reaksi alergi pada manusia setelah mengkonsumsi ikan tersebut. Banyaknya parasit Anisakis sp dalam tubuh ikan juga ditemukan pada ikan selar bentong sebesar 85,7 \% (Friska Tamba et al,2012) yang menunjukkan bahwa cacing Anisakis sp menjadi parasit yang perlu diwaspadai.

\section{KESIMPULAN}

Ikan tongkol yang didaratkan di TPI kota Pekalongan pada bulan Maret April 2017 pada sampel dengan ukuran 19
- 33cm telah terinfeksi larva Anisakis sp. Jumlah Anisakis sp terbesar ditemukan dalam usus dan paling sedikit pada hati. Nilai prevalensi Anisakis sp pada ikan tongkol ukuran 25-33 cm mencapai $88 \%$ sedangkan pada kelompok ukuran 19-24 $\mathrm{cm}$ 60\%. Derajat infeksi pada ikan kelompok ukuran 25-33 cm 16,5 ekor per ikan sedangkan kelompok ikan 19-24 cmsebesar 12,6 ekor per ikan. Data tersebut menunjukkan bahwa ikan dengan ukuran lebih besar lebih rentan terinfeksi cacing Anisakis sp daripada ikan yang lebih kecil.

\section{DAFTAR PUSTAKA}

Awik, P.D.N., D. Hidayati, P. Ressa, dan E. Setiawan. (2007). Pola Distribusi Anisakis sp pada Usus Halus Ikan Kakap Putih (Lates calcarifer) yang Tertangkap di TPI Brondong, Lamongan. Prodi Biologi Institut Teknologi Sepuluh Nopember Surabaya.

Friska Tamba, M. I Made Damriyasa, Nyoman Adi suratma, Stefan Theisen (2012). Prevalensi dan Distribusi cacing Pada berbagi Organ Selar Bentong. Indonesia Medicus Veterinus. ( Vol 1 (4) : 555-566p

Hassan, M.A, Abd El Mohsen. H Mohamed and Osman, H.A.M (2013). Some Studies on anisakidae in marine fish of coastal waters near Jakarta, 
Indonesia. Am Journal Trop. Med. Hyg $27: 51-54$

Kimple, S. H. W. Palm, S. Rupckert, and U. Piatkowski (2004). The life cycle of Anisakis sp Simplex in the Norwegian Deep (Northen Nort Sea). Parasitol Res. 94 p1-9.

Lorenzo, S (2000) "Usefulness of Currently Available Methods for The Diagnosis of Anisakis $s p$ simplex allergy".Allergy 55, 627-633. [18] Grabda, Marine Fish Parasitology. PWN - Poloish Scientific Publisher

Noble E.R and Noble, G.A (1989). Parasitologi. Biologi Parasit Hewan. Edisi kelima. UGM Press. Yogyakarta

Polimeno, L. (2010). Anisakiasis, an underestimated infection: effect on intestinal permeability of Anisakis sp simplek-sensitized patients. Journal of Disease of Organisans. Hamburg, 90 (1)

Pozio.E. (2013). Integrating animal health Sanger.

G.(2010).OksidasiLemakIkan

Tongkol(Auxisthazard)

AsapYang

DirendamDalamLarutan

Ekstrak Daun. Pacific Journal $.2 .870-873 \mathrm{p}$.

Robert and Janov, Foundations of Parasitology. (2000) New York : The McGraw Hill Companies.

Rohde. (1994). Disease caused by metazoan, helminth. Disease marine animals. Hamburg: Biolische Anstalt Helgoland
Rueckert, S., W. Hagen, A. T. Yuniar, and H. W. Palm. "Metazoan Fish Parasites of Segara Anakan Lagoon, Indonesia, and their Potential Use as Biological Indicators". Reg. Environ Change 9, (2009) 315-328. [10] R.I.

Sanger. G. 2010. Oksidasi Lemak Ikan Tongkol (Auxis thazard) Asap Yang Direndam Dalam Larutan Ekstrak Daun. Pacific Journal .2 . 870-873.

Semarariana,W.Y.,Suratma,N.a.,Oka,I.B. M,(2012), Infeksi larvacacing Anisakis sp. Pada ikan layur (Trichiurus lepturus), Indonesia medicus veterinus, Vol 1 (2): 293-304.

Williams, H., and Jones, A., (1993). Parasitic Worm of Fish. Taylor and Francis Ltd., London, United Kingdom: 593 pp

Zubaidy, Al (2010). Third-stage larvae of Anisakis sp simplex-sensitized patient. Yemen Coast.in the Red Sea Fishes, Vol 21 No 1 Mar. Science 